\title{
Lucian in Byzantine Hades - A Note on the Lucianic Cento
}

\section{Przemysław Tadeusz Marciniak}

\begin{abstract}
This article discusses the relatively unknown dialogue composed from lines lifted from the writings of Lucian. It is argued that the primary purpose of this text might be didactic.
\end{abstract}

\section{Keywords}

Lucian; Byzantine literature; reception 
Codex Ambrosianus gr. 655 (P 270 sup.) on folios 82-83 transmits a dialogue among Charon, Hermes, and Alexander the Great, though the conversation between Alexander and Charon accounts for most of the work. This dialogue is a centonic work, constructed mostly of lines from Lucian's dialogues (primarily Dialogues of the Dead and Dialogues of the Gods) and an Aesopic fable (Perry no. 60). Following the subversive Lucianic presentation of ancient figures, Hermes is depicted as a coward, and Alexander as a megalomaniac consumed by the desire to conquer this and other worlds.

The manuscript which transmits this text dates from the fifteenth or sixteenth century ${ }^{1}$ and has a highly eclectic nature. Partially consisting of re-used folios, it contains both ancient texts (Hesiod, Theocritus, Proclus) and more contemporary works (a letter from Demetrius Chalkokondyles to the prince of Urbino, a translation of the Russian tsar's letter to Anthony Eparchus). In the folios immediately following the text under discussion are Themistius' oration to the emperor, De bellis by Procopius, and finally, Gennadius' inscription on the tomb of Constantine the Great. These works all address great rulers from the past, perhaps accounting for the inclusion of the dialogue about Alexander in this selection. ${ }^{2}$ The dialogue itself is in folios 82 and 83 and is preceded by the Italian phrase dialogo Greco ad imitatione di Luciano ("Greek dialogue imitating Lucian"). It was proposed that the scribe was David Colvill, but Mercati already cast doubt on this attribution. ${ }^{3}$ A first edition of the text was prepared by Natale Caccia ${ }^{4}$ and a second in 1971 by Orsolya Karsay, who was unaware of Caccia's edition. ${ }^{5}$ Sometime later, T. M. Sokolova published a Russian translation, which was the only modern translation of the work until the recent Polish one. ${ }^{6}$

The chronology of this piece has been debated, but no definitive conclusion has been reached. Comparing a passage from this dialogue to a work by Ulric Hutten, Caccia proposed authorship by an unknown Byzantine (un'ignoto autore bizantino). ${ }^{7}$ Karsay opted for the Palaiologan period, whereas other authors suggested the twelfth century. ${ }^{8}$ The latter two are both undoubtedly attractive options. The Komnenian period saw unusual interest in Lucianic writings, prompted primarily by one influential writer - Theodore Prodromos. ${ }^{9}$ In contrast to Komnenian writers, Palaiologan scholars seem to have been more interested in linguistic and textual matters ${ }^{10}$ because there are no imitations of

1 For the description of the dialogue see Martini \& Bassi (1978²: p. 734).

2 On Alexander's reception in Byzantium see Gleixner (1961).

3 Mercati (1937: p. 107): "A dir vero mi sembra aver poco della mano di lui".

4 Caccia (1915).

5 Karsay (1971: pp. 383-391).

6 Sokolova (1975: pp. 195-203).

7 Caccia (1915: p. 107).

8 Lampakis (1982: pp. 94-95). Lampakis' hypothesis is repeated by Garland (2000/2001: pp. 481-489).

9 Marciniak (2017).

10 See for instance the use of words taken from Lucian in Thomas Magistros (Ritschelius 1970: pp. 431-434). 
Lucian confidently dated from this period (even though there is a plethora of instances where Palaiologan scholars use, discuss and comment on Lucian's works). ${ }^{11}$ To what extent an anonymous satirical monody that shows a dependence on Lucian, should be understood as a direct imitation of the Syrian satirist, requires further investigation. ${ }^{12}$ To complicate things even further, it could be argued that it is not impossible that a Renaissance writer penned this text as Lucian was a very popular writer in that period. ${ }^{13}$

Thus, no compelling argument, whether paleographical or internal, points us in the right direction and confirms the dating beyond any doubt. The arguments regarding the dating offered by the scholars rest upon an assumption that this text might fit certain periods better than the others. Therefore, the question to be asked is whether this dialogue is a typical product of its times or rather an exception. None of the preserved works modelled on Lucian is a cento and what is more none of them is written in such a way as to look like an almost exact "replica" of a Lucianic work. I am inclined to think that the text studied here is rather unusual and therefore any attempt at dating it is in fact pointless.

The editors of the text identified the source material used to compose this dialogue. ${ }^{14}$ Although some of the similia appear somewhat far-fetched, there is no doubt that the text studied is a cento, a work pieced together from fragments of other works. Cento as such is by no means an unusual technique in the Byzantine period. Twelfth-century Byzantium saw the production of other centonic works: the letters of the monk Jacob ${ }^{15}$ and possibly Christos Paschon. Such works composed mostly or exclusively from the fragments of other texts could have both educational and entertainment value depending on the performative context of their presentation. ${ }^{16}$ The audience, whether students or members of a theatron, had to play the game of decoding the source of quotations to enjoy these texts. ${ }^{17}$

11 Among others see Nikephoros Gregoras (Bekker \& Schopen 1829-1855: Vol. 2, p. 924); on Michael Gabras' and Theodoros Phialites' correspondence regarding Lucian see Christidis (2015). The dating of the three dialogues ascribed to John Katrares is uncertain, while the authorship itself is unsure, and the dependence on Lucian requires further investigation. Editions: Kroll \& Viereck (1895). The editio princeps, based on one manuscript only, was published in Copenhagen (Bloch 1830). On Hermodotos and Musokles see Elter (1898: pp. 5-54). On the dialogues see Anonymus Byzantinus, Lebenslehren in drei Dialogen: Hermodotos, Musokles, Hermippos (Schönberger \& Schönberger 2010), with further bibliography. On the authorship of the dialogues see Hohlweg (1995). On the possible dependence on Lucian see Schumacher (1898).

12 Sideras (2002). Sideras thought this text to be composed in the twelfth century. More recent analysis point, however, to the Palaiologan period, see Bianconi (2006).

13 Marsch (1998).

14 Christidis (1980).

15 Jeffreys \& Jeffreys (2009); Jeffreys (2010).

16 See for instance Zagklas (2014).

17 Hunger (1976), see also Vakonakis (2011). 
Robert Wilken claims that centos could be composed from the writings of any important author in ancient times, ${ }^{18}$ but later sources mention only Homer and Vergil in the Greek and Latin traditions, respectively. ${ }^{19}$ Consequently, the works used as the primary texts consisted of poetry. ${ }^{20}$ The cento studied here is somewhat exceptional (even though not completely unique in Byzantium) because it is based on the writings of a single prose author. Moreover, a standard cento is composed exclusively from lines (verses or semiverses) borrowed from a given author (in Homeric centos, the Iliad and Odyssey), allowing little scope for the author's creativity in writing original text. ${ }^{21}$ This traditional view of the cento is once again challenged when considering Christos Paschon, which consists of both borrowed and original lines. ${ }^{22}$ The Lucianic cento then is closer to Christos Paschon because, in addition to lines from Lucian's works, it contains certain parts that must have been penned by its author.

This dialogue, being a prose work, has an even more complicated relationship with its hypotexts. The anonymous author uses often fragments of phrases rather than whole sentence, sometimes with slight changes:

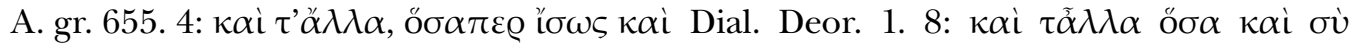

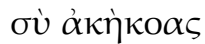

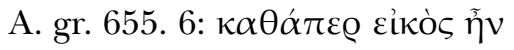

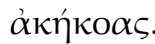

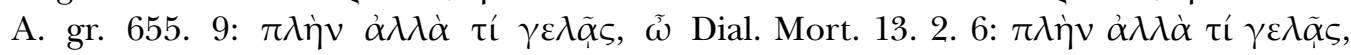
Xóowv;

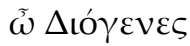

The success of a cento required that both the author and the audience knew the primary text(s) - or using Genette's terminology, the hypotext - and that the audience could appreciate the centonist's alterations. Therefore, the full message of the cento could be completely understood only by reading the recycled lines against the hypotext. The case of the cento analyzed here is yet again unique. Many lines concerning Alexander (his conquests, his alleged parentage from Ammon) in the primary text discuss exactly the same issues as the cento and, therefore, do not add any meaning but reinforce the existing one. Other lines (like the ones quoted above) seem to be used for grammatical rather than literary reasons (it would be impossible for the potential recipients of the text to locate completely decontextualized phrases such as $\kappa \alpha \theta \dot{\alpha} \pi \varepsilon \varrho$ cikò $\tilde{\eta} v)$. In other words, the works of Lucian might have been used as lexicographical repositories and consequently this cento could have been understood as an advanced exercise in "prose composition". Yet, this doesn't exclude a possibility that certain lines when read against

18 Wilken (1967: p. 28). Lucian mentions one grammarian Histiaeus who composed a poem combining lines from Pindar, Hesiod, and Anacreon (Lapit. 17), on this fragment see Rondholz (2012: p. 7).

19 McGill (2005). A short introduction to Christian centos based on ancient poets see Meconi (2004). On Homer and Vergil as the main sources see Rondholz (2012: p. 25).

20 See Usher (1997b: pp. 305-321).

21 For Eudocia's literary technique see Usher (1997a and 1998).

22 Marciniak (2004). 
the original context might offer an additional meaning. The cento depicts Hermes as a cowardly and rather unstable figure (Karsay 1971: p. 389, 26-29). Explaining his erratic

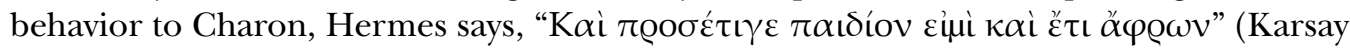

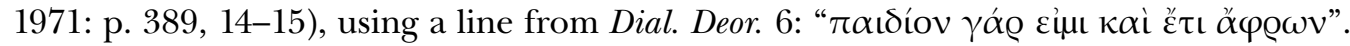
In this line, Eros defends him to Zeus by saying that he is only an unwise child. Zeus replies that Eros is in fact much older than Iapetos himself (a traditional description of a person who is truly old). Perhaps the joke here is that Hermes, who proved himself to be a skilled inventor and thief while still a child, uses an excuse as improbable as it was in case of Eros.

I would like to argue that the peculiar character of this cento could be explained by the purpose of the text. It is a well-known fact that Lucian was used $^{23}$ and imitated ${ }^{24}$ in education. The didactic purpose of the text was already suggested by Hunger. ${ }^{25}$ There exist schede, or grammatical exercises, including some dating from the twelfth century, based on Lucian's texts. ${ }^{26}$ Popularity of Lucian as a "school author" is well attested in the Palaiologan period, both in the writings of the writers of the period, ${ }^{27}$ and by the great number of extant manuscripts. Similarly, Lucian's works were widely used to teach ancient Greek during the Renaissance. ${ }^{28}$ The very first example arises from Manuel Chrysoloras, who came to Florence in 1397 and taught the language to mostly Greekless Italians. Chrysoloras brought with him a manuscript containing seventy-five works of Lucian (and the satire Timarion) - nearly all the extant works of Lucian, including the Dialogues of the Dead (the source of lines used to compose the cento under examination). ${ }^{29}$ However, the manuscript Vat. Urb. gr. 121, which belonged to a student of Chrysoloras, shows that neither the Dialogues of the Dead nor the Dialogues of the Gods were among the texts the Byzantine scholar used to instruct his Florentine disciples. ${ }^{30}$ Yet, it has to be noted that Italian scholars and writers were much more interested in translating Lucian into Latin. The earliest such translations date to 1400 and numbered almost twenty-six by $1470 .{ }^{31}$ Therefore, in different periods the writings of Lucian were used - in various degrees - for didactic purposes. It may therefore be tempting to see the text in question

23 Marciniak (2017); Markopoulos (2006: p. 89).

24 Migliorini (2010).

25 Hunger (1978: p. 155).

26 See Vassis (2002: p. 56, no. 133): Michael Attikos: a paraphrase of Lucian's Kataplous [fol. 188r-v]; Idem

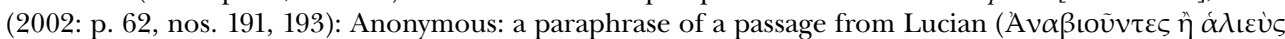

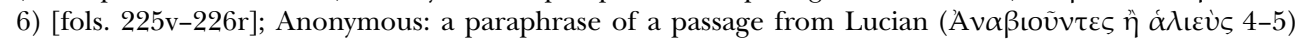
[fol. 226r-v]. On schede see Agapitos (2014: pp. 1-22).

27 Christidis (2015).

28 Ciccolella (2008: p. 135).

29 Marsch (1998: p. 13).

30 For the thorough analysis of the manuscript see Berti (1987).

31 These were the translations of Charon and Timon. Charon was translated into Latin by the unidentified Florentine student of Chrysoloras, see Marsch (1998: p. 16). Timon, authored by one Bertholdus, can be dated to 1400, see Goldschmidt (1951: p. 12). Italian scholars also imitated the Syrian by writing Lucianiclike pieces in Latin rather than Greek. 
as a further evidence of the intensified interest in writing texts modeled on Lucianic works and in using Lucian's writings in the didactic process.

The aim of the text, if it had a specific one, is difficult to pinpoint precisely. Unlike Eudocia's Homeric centos and Christos Paschon, this is not an attempt to tell a Christian story using pagan texts. This text is closer to the Vergilian centos which recount mythical stories, and in this sense, it is unique in all of Byzantine literature. However, it is difficult to determine whether it was penned by a teacher for his students as an exercise in recognizing Lucianic lines or by a student tasked with imitating Lucian's Dialogues of the Dead. Yet again, perhaps it is unwise to assume that a text had one fixed and unchangeable purpose. A text, which originated in an "educational" milieu or for didactic purposes, might have been re-used and could have acquired a new "life" in a different performative context. ${ }^{32}$ Therefore, the dialogue under discussion when "performed" outside of the school context might have been read as a comic text.

In Against the Heresies, Irenaeus of Lyons ( $2^{\text {nd }}$ century AD) quotes a ten-line cento on Hercules composed of lines taken from Homer. Irenaeus concludes: "One who is wellversed in Homeric themes will recognize the verse, but he will not recognize the theme, since he knows that some of them were spoken of Ulysses, others of Hercules himself, others of Priam, others of Menelaus and Agamemnon." ${ }^{33}$ This statement is a clear indication that the text's well-educated audience could recognize the initial context. As Rondholz rightly notes, Homer and Vergil were almost exclusively used as sources for centos because "only Homer and Vergil were that ingrained in people's minds" ${ }^{34} \mathrm{I}$ argue that Lucianic writings were chosen as a model for this cento for exactly the same reason. Even if certain phrases were too generic and could have not been recognized by recipients of the texts, there are still passages whose initial context is obvious, e.g. lines 59-60 are almost verbatim taken from Tim. 34. Most of the lines come from the Dialogues of the Dead and Dialogues of the Gods, which were the most popular works of Lucian judging by the number of manuscripts containing them ${ }^{35}$ and the testimonies of Byzantine writers throughout the Byzantine period. Lucian's writings became such an important part of Byzantine education (especially in the later period) that their popularity guaranteed that recipients of this text would be able to place the lines in their initial context.

By way of conclusion, I propose that the text under discussion was most likely penned as a didactic exercise. Its uniqueness lies in the use of lines from a prose author instead of Homer. I also argue that this cento is yet more proof of Lucian's popularity as a school author and that his writings were widely known among the educated Byzantines.

32 Zagklas (2014).

33 Adv. Haereses I, 9,4 (Transl. Unger 1992).

34 Rondholz (2012: p. 25).

35 Wittek (1952). 


\section{Bibliography}

Agapitos, P. (2014). Grammar, Genre and Politics in Komnenian Constantinople: Redefining a Scientific Paradigm in the History of Byzantine Literature. Jahrbuch der Österreichischen Byzantinistik, 64, 1-22.

Bekker, I., \& Schopen, L. (Eds.). (1829-1855). Nicephori Gregorae historiae Byzantinae (3 Vols.). Bonn: Weber.

Berti, E. (1987). Alla scuola do Manuele Crisolora. Lettura e commento do Luciano. Rinascimento, 27, 3-73.

Bianconi, D. (2006). Qualcosa di nuovo su Giovanni Catrario. Medioevo Greco, 6, 69-91.

Bloch, O. D. (Ed.). (1830). Incerti Auctoris Christiani Dialogus Hermippus sive de Astrologia Libri II. Copenhagen: Brunner.

Caccia, N. (1915). Note su la Fortuna di Luciano nel Rinascimento: Le Versioni e i Dialoghi Satirici di Erasmo da Rotterdam e di Ulrico Hutten. Milano: C. Signorelli.

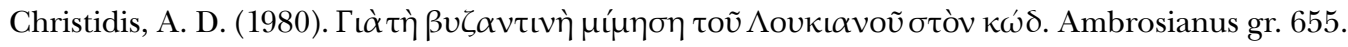
Hellenika, 32, 86-91.

Christidis, A. D. (2015). Theodore Phialites and Michael Gabras: A Supporter and an Opponent of Lucian in the 14th Century. In M. Tziatzi et al. (Eds.), Lemmata. Beiträge zum Gedenken an Christos Theodoridis (pp. 542-549). Berlin: De Gruyter.

Ciccolella, F. (2008). Donati Graeci. Learning Greek in the Renaissance. Leiden - Boston: Brill.

Cramer, J. A. (Ed.). (1839). Anecdota Greca (Vol. I). Oxford: Typographeum Academicum.

Elter, A. (1898). Io. Katrarii Hermodotus et Musocles dialogi. In Natalicia regis augustissimi Guilelmi II imperatoris Germanorum (pp. 5-54). Bonnae: C. Georgi.

Garland, L. (2000/2001). A Treasury Minister in Hell - a Little Known Dialogue of the Dead of the Late Twelfth Century. Modern Greek Studies Yearbook, 17, 481-489.

Gleixner, H. J. (1961). Das Alexanderbild der Byzantiner (Munich, unpublished PhD diss.).

Goldschmidt, E. P. (1951). The First Edition of Lucian of Samosata. Journal of the Warburg and Courtauld Institutes, 14(1/2), 7-20.

Hohlweg, A. (1995). Drei anonyme Texte suchen einen Autor. Byzantiaka, 15, 15-45.

Hunger, H. (1976). Thukydides bei Johannes Kantakuzenos. Beobachtungen zur Mimesis. Jahrbuch der Österreichischen Byzantinistik, 25, 181-193.

Hunger, H. (1978). Die hochsprachliche profane Literatur der Byzantiner (Vol. 2). München: Beck.

Ideler, I. L. (Ed.). (1841). Physici et Medici Graeci Minores. Berlin: Typis et impensis G. Reimeri.

Jeffreys, E. (2010). Mimesis in an Ecclesiastical Context. The Case of Iakovos Monachos. In A. Rhoby, \& E. Schiffer (Eds.), Imitatio - Aemulatio - Variatio. Akten des internationalen wissenschaftichen Symposions zur byzantinischen Sprache und Literatur; Wien, 22.-25. Oktober 2008 (pp. 153-164). Wien: Verlag der Österreichischen Akademie der Wissenschaften.

Jeffreys, E., \& Jeffreys, M. (Eds.). (2009). Iacobi monachi epistulae. Turnhout: Brepols.

Karsay, O. (1971). Eine byzantinische Imitation von Lukianos. Acta Antiqua Academiae Scientiarum Hungaricae, 19, 383-391.

Kroll, W., \& Viereck, P. (Eds.). (1895). Anonymi Christiani Hermippus De Astrologia Dialogus. Leipzig: Teubneri. 


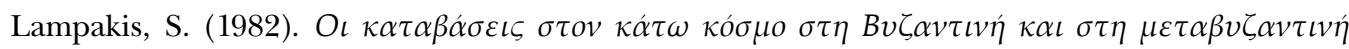

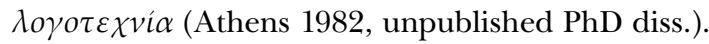

Marciniak, P. (2004). Greek Drama in Byzantine Times. Katowice: Wydawn. Uniwersytetu Śląskiego.

Marciniak, P. (2016). Reinventing Lucian in Byzantium. Dumbarton Oaks Papers, 70, 209-224.

Markopoulos, A. (2006). De la structure de l'école byzantine. Le maître, le livres et le processus éducatif. In B. Mondrain (Ed.), Lire et écrire à Byzance (pp. 85-96). Paris: Assoc. des Amis du Centre d'Histoire et Civilisation de Byzance.

Marsch, D. (1998). Lucian and the Latins. Humor and Humanism in the Early Renaissance. Ann Arbor: Univ. of Michigan Press.

Martini, E., \& Bassi, D. (1978). Catalogus codicum Graecorum Bibliothecae Ambrosianae (2 vols.). Hildesheim: Olms.

McGill, S. (2005). Virgil recomposed. The mythological and secular centos in Antiquity. Oxford: Oxford University Press.

Meconi, D. V. (2004). The Christian cento and the evangelization of Christian culture. Logos: A Journal of Catholic Thought and Culture, 7(4), 109-132.

Mercati, S. G. (1937). Il Catalogo dei codici dell' Escuriale compilato avanti l'incendio del 1671 da D. Colvill. In Opere Minori: raccolte in occasione del settantesimo natalizio sotto gli auspicii di s. s. Pio XI (Vol. 2: 1897-1906; pp. 100-108). Città del Vaticano: Biblioteca apostolica vaticana.

Migliorini, T. (2010). Gli scritti satirici in greco letterario di Teodoro Prodromo: Introduzione, edizione, traduzione e commenti (Pisa, unpublished PhD diss.).

Miller, E. (Ed.). (1855-1857). Manuelis Philae Carmina (2 vols.). Paris: [Franck].

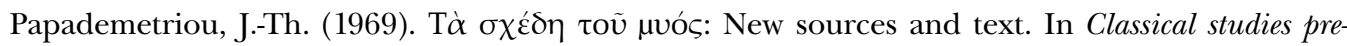
sented to Ben Edwin Perry by his students and the colleagues at the University of Illinois, 1924-1960 (Illinois studies in language and literature, 58; pp. 210-222). Urbana - Chicago - London: Univ. of Illinois Press.

Ritschelius, F. (Ed.). (1832). Thomae Magistri... Ecloga vocum Atticarum. Halle: Libraria Orphanotrophei (repr. Hildesheim: Olms 1970).

Rondholz, A. (2012). The versatile needle: Hosidius Geta's cento Medea and its tradition. Berlin - Boston: De Gruyter.

Schönberger, O., \& Schönberger, E. (Eds.). (2010). Anonymus Byzantinus. Lebenslehren in drei Dialogen: Hermodotos, Musokles, Hermippos. Würzburg: Königshausen \& Neumann.

Schumacher, F. (1898). De Ioanne Katrario Luciani imitatore. Bonnae: Hauptmanni.

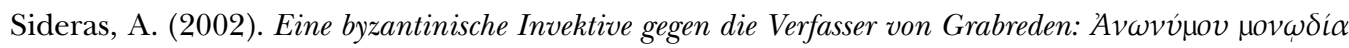

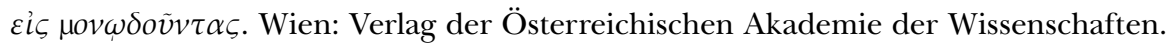

Sokolova, T. M. (1975). Ešče odno wizantijskoje 'podražanie' Lukianu. In L. A. Frejberg (Ed.), Antičnost' i Vizantija (pp. 195-203). Moscow: Izdatel'stvo Nauka.

Unger, D. J. (Transl.). (1992). St. Irenaeus of Lyons: Against the heresies. New York: Paulist Press.

Usher, M. D. (1997a). Homeric stitchings: a new text and interpretation of the Homeric centos (Chicago, unpublished PhD diss.).

Usher, M. D. (1997b). Prolegomenon to the Homeric Centos. The American Journal of Philology, 118(2), 305-321.

Usher, M. D. (1998). Homeric stitchings: The Homeric centos of the empress Eudocia. Lanham, Md.: Rowman \& Littlefield Publishers. 
Vakonakis, N. (2011). Das griechische Drama auf dem Weg nach Byzanz: Der euripideische Cento Christos Paschon. Tübingen: Gunter Narr Verlag.

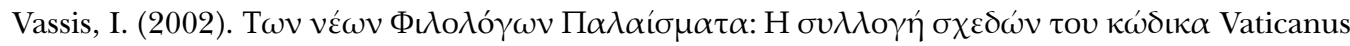
Palatinus gr. 92. Hellenika, 52, 37-68.

Wilken, R. L. (1967). The Homeric Cento in Irenaeus, "Adversus Haereses I, 9,4". Vigiliae Christianae, 21(1), 25-33.

Wittek, M. (1952). Bibliographie. Liste des manuscrits de Lucien. Scriptorium, 6, 309-323.

Zagklas, N. (2014). Theodore Prodromos: The Neglected Poems and Epigrams. Edition, Translation, and Commentary (Vienna, PhD. diss.), pp. 70-84.

Prof. Dr. Przemysław Tadeusz Marciniak / przemyslaw.marciniak@us.edu.pl

Center for Studies on Byzantine Literature and Reception

University of Silesia, Faculty of Philology

pl. Sejmu Śląskiego 1, pok. 117, 40-032 Katowice, Poland 
